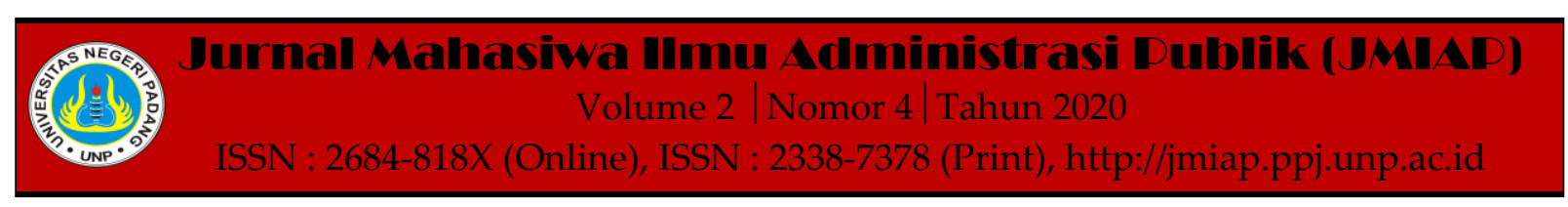

\title{
EFEKTIVITAS PELAKSANAAN PROGRAM SEKOLAH ADIWIYATA DI SMA NEGERI 15 KOTA PADANG
}

\author{
Arin Wiwin Diana ${ }^{1(a)}$, Adil Mubarak ${ }^{2(b)}$ \\ ${ }^{1}$ Jurusan Ilmu Administrasi Negara, Universitas Negeri Padang \\ ${ }^{2}$ Jurusan Ilmu Administrasi Negara, Universitas Negeri Padang \\ a)arinwiwindiana@yahoo.com, ${ }^{\text {b) }}$ adilmubarak08@yahoo.co.id
}

\begin{abstract}
The Adiwiyata school program in the city of Padang, especially at SMA Negeri 15 Padang, has actually been going on since 2013, but in reality there is still low awareness of environmental care from the point of view of the school community, especially students and other devices, this can be proven that the school is still not clean and does not throw garbage yet. in place. This study aims to determine the implementation and effectiveness of the Adiwiyata school program implemented at SMA Negeri 15 Padang. This study uses the theory of successful implementation of a program (According to Weimer 7 Vinning: 2009) and the theory of effectiveness according to Budiani in (Amelia, 2015) then this research is descriptive using qualitative methods. The data collection technique is done by interview, observation, documentation study so that accurate conclusions are drawn from the data that has been obtained. The results showed that the implementation of the Adiwiyata school program implemented in SMA Negeri 15 Padang was quite effective but not $100 \%$. This was evidenced by the lack of clarity regarding the prospects of this program in writing at SMA Negeri 15 Padang.
\end{abstract}

Keywords : Effectiveness, Adiwiyata School Program, Environmental Care

Corresponding author. Email. arinwiwindiana@yahoo.com

How to cite this article. Diana, A. Wiwin \& Mubarak, A. (2020). Efektivitas Pelaksanaan Program Sekolah Adiwiyata di SMA Negeri 15 Kota Padang. Jurnal Mahasiwa Ilmu Administrasi Publik (JMIAP) Jurusan Ilmu Administrasi Negara Fakultas Ilmu Sosial Universitas Negeri Padang, Volume 3 (2), Hal. 105-114.

http://jmiap.ppj.unp.ac.id

ISSN : 2684-818X (Online), ISSN : 2338-7378 (Print)

Copyright@2020. Published by Labor Jurusan Ilmu Administrasi Negara FIS UNP, Padang 


\section{PENDAHULUAN}

Pada umumnya kehidupan manusia tidak akan pernah lepas dari lingkungan sekitarnya. Hal ini disebabkan karena seluruh kebutuhan pokok hidup manusia pada dasarnya mengandalkan sumber daya alam yang ada dan bergantung terhadap kondisi lingkungan. Lingkungan hidup merupakan ruang interaksi antara makhluk hidup dan sumber daya alam. Sebagai manusia yang dapat memenuhi kebutuhannya dengan memanfaatkan sumber daya alam, berdampak besar terhadap kondisi lingkungan hidupnya masing-masing. Perilaku manusia dalam pemanfaatan sumber daya alam memiliki dampak positif dan dampak negatif. Jika manusia tersebut menggunakan sumber daya alam yang tersedia secara tidak bijaksana maka akan menimbulkan masalah lingkungan. Permasalahan lingkungan berupa pencemaran dan kerusakan lingkungan biasanya berdampak negatif bagi kehidupan masyarakat.

Terjadinya kerusakan serta pencemaran lingkungan di Indonesia sudah terjadi diberbagai daerah yang selalu bertambah setiap tahun nya, bermacam bentuk dari akibat kerusakan dan pencemaran yang dapat dilihat sepeerti banjir, longsor, kebakaran hutan, kerusakan terumbu karang, pencemaran udara dan air. Penyebab dari itu sendiri adalah ulah dari perbuatan manusia melalui berbagai kegiatan yang (terkadang) menempatkan alam sebagai bahan komoditi yang terus dieksploitasi. Dengan demikian, lingkungan justru menjadi media pembuangan (limbah dan sampah) sebagai bagian dari hasil eksploitasi tersebut.(Kahfi, 2014).

Permasalahan yang ada dilingkungan baik yang bentuk nya berupa pencemaran serta eksploitasi sumber daya alam yang wajib untuk dijadikan bahan utama untuk pertimbangan dalam melakukan semua jenis kegiatan pembangunan atau kegiatan pemenuhan kebutuhan hidup manusia sehari-hari. Hal ini baik untuk meminimalisir terjadinya kerusakan lingkungan. Pada saat ini, masyarakat umum serta pelajar pada khususnya yang belum mempunyai kesadaran tinggi pada kondisi lingkungannya. Pada dasarnya untuk menaggulangi kerusakan yang terjadi dilingkungan juga diperlukan kesadaran dari seluruh masyarakat yang ada dilingkungan itu sendiri. Berkaitan dengan hal ini sikap individu serta masyarakat terhadap pelestarian sumber daya alam dan lingkungan masih cenderung tidak peduli, maka dari itu harus ada kesadaran dalam mengubah perilaku menjadi prioritas utama dalam mengatasi krisis lingkungan. Salah satu cara untuk mengubah atau memperbaiki perilaku salah satunya dengan melalui jalur pendidikan.

Didalam Peraturan Menteri Lingkungan Hidup RI No 5 Tahun 2013 mengenai Pedoman Pelaksanan Program Sekolah Adiwiyata. Pendidikan merupakan suatu usaha yang terencana dalam mengubah suasana belajar atau progress pembelajaran sehingga peserta didik menjadi aktif dalam mengembangkan kemampuan agar mereka memilki ilmu keagamaan, sikap, kepribadian, akhlak dan kecerdasan sehingga berguna untuk dirinya, masyarakat serta bangsa dan negara. Sekolah merupakan suatu lembaga pendidikan yang sangat diharapkan agar dapat menjadi contoh oleh peserta didik terhadap kepdulian lingkungan sekitarnya sehingga membentuk perilaku peduli pada lingkungan sekitar.(Sumarlin, 2013).

SMA N 15 Padang yaitu sekolah yang berhasil mendapat gelar sebagai salah satu sekolah Adiwiyata tingkat SMA di kota Padang. Namun, kenyataan yang terjadi dilapangan tidak sesuai dengan gelar adiwiyata yang telah didapatkan di SMA Negeri 15. Berdasarkan temuan penelitian bahwa program sekolah Adiwiyata belum berdampak secara efektif pada diri siswa, karena masih banyak perilaku siswa yang tidak ramah terhadap lingkungan, berupa kebiasaan membuang sampah sembarangan, tidak mau menjaga keindahan dan memelihara ruang hijau di sekolah, menjaga kebersihan di wc dan 
kamar mandi, serta menjaga kebersihan lingkungan diluar sekolah. Hal ini menandakan perilaku peduli lingkungan belum tertanam dalam diri siswa padahal tujuan program tersebut ialah untuk menghasilkan siswa yang peduli terhadap pelestarian lingkungan hidup.

\section{TINJAUAN PUSTAKA}

\section{Konsep Efektivitas}

Pada dasarnya kata efektif sendiri berasal dari Bahasa inggris effective artinya adalah seberapa hasil dari sebuah program terhadap pencapaiannya. Efektivitas umumnya berasal dari kata "efek" digunakan sebagai kata sebab akibat. Efektivitas juga dapat dinilai sebagai sebab suatu variable. Efektivitas merupakan suatu program yang telah direncanakan sebelumnya agar bisa dinilai berhasil atau tidaknya suatu kegiatan yang telah dibuat.

Menurut Duncan yang dikutip Richard M. Steers (1985:53) mengatakan ukuran dari efektivitas yang bisa digunakan sebagai pengukuran efektivitas pelaksanaan dari suatu program, baik program yang dilaksanakan oleh instansi ataupun perusahaan swasta yang terdiri dari 3 (tiga) aspek, adalah sebagai berikut :

1) Pencapaian Tujuan

Pencapaian tujuan sendiri adalah seluruh pencapaian tujuan yang harus dinilai sebagai suatu proses. Oleh sebab itu, supaya suatu pencapaian dapat dilihat sebagai tujuan akhir dan semakin terjamin dibutuhkan tahap periodesasinya.

2) Integrasi

Integrasi adalah suatu ukuran pada tingkatan kemampuan dalam sebuah organisasi dengan dilakukan kegiatan dari program yang sudah disepakati dan membuat sebuah sosialisasi dengan orang lain.

3) Adaptasi

Adaptasi merupakan suatu kemampuan orgnisasi agar bisa menyesuaikan diri dan lingkungannya. Adaptasi ada beberapa factor yang disebut dengan pembahruan sumber daya khususnya meningkatkan sumber daya manusia yang ada serta pembaharuan strategi pelaksanaan program yang disesuaikan dengan perkembangan zaman dan kebutuhan yang ada.

Menurut Budiani dalam (Amelia, 2015) efektivitas dari sebuah program bisa dilakukan dan menggunakan variabel dapat dilihat sebagai berikut:

a) Ketepatan sebuah sasaran program yang sejauh mana anggota dari program yang tepat dengan sasaran yang sudah ditentukan sebelumnya

b) Sosialisasi program adalah suatu kemampuan dalam menyelenggarakan sebuah program hingga informasi yang diperoleh pada pelaksanaan program bisa sampai kepada masyarakat umumnya dan individu program pada khususnya.

c) Pencapaian dari Tujuan program adalah sejauh apa sesuainya hasil dan pelaksanaan program tersebut dengan penetapan program sebelumnya.

d) Pemantuan program merupakan suatu kegiatan yang dapat dilakukan setelah pelaksanaan sebuah program sebagai bentuk dari perhatian kepada peserta program itu sendiri.

\section{Implementasi program}

Menurut Weimer \& Vining dalam (Ismail Nawawi, 2009) mengatakan ada 3 indikator yang dapat menentukan keberhasilan implementasi program yaitu:

a) Logika dari suatu program

b) Sebuah kebijakan harus sesuai

c) Kemampuan implementor

Hasil dari sebuah implementasi kebijakan dapat dilihat dari proses implementasi (perspektif proses) serta hasil yang dicapai (perspektif hasil). Untuk perspektif proses sendiri sebuah program dari pemerinyah bisa dikatakan berhasil kalau pelaksanaannya dapat sesuai dengan petunjuk serta ketentuan dari pelaksanaan yang dibuat sendiri oleh pelaksana program anatara lain dengan tata cara, prosedur 
pelaksanaan kelompok sasaran serta manfaatnya .

Perspektif hasil, sebuah program bisa dikatan berhasil jika programnya membawa dampak sesuai dengan yang diinginkan. Suatu program bisa dikatakan berhasil jika dilihat dari sudut prosesnya sendiri dan bisa dikatakan gagal jika tidak sesuai. Maka sebuah implementasi kebijakan dapat dikatakan berhasil jika sudah ada dampak anatar hasil dan proses yang sudah dicapai. (Akib, 2012).

\section{Konsep Adiwiyata}

Program dari sekolah adiwiyata diharapkan bisa memacu terciptanya sebuah lingkungan nyaman pada proses pembelajaran dan bisa menimbulkan tanggungjawab pada lingkungan untuk pembangun yang berkelanjutan. Kesadaran siswa, upaya yang diharapkan agar siswa memilki komitmen terhadap nilai-nilai moral dalam kehidupannya. Teori dari Thomas Lickona, teori yang membahas tentang 3 komponen mendasar pada kehidupan yaitu :

a) Pengetahuan moral

b) Nilai-nilai moral

c) Perasaan moral

Bahwasannya 3 hal yang penting dari teori diatas agar lingkungan tetap terjaga keasrian, keindahan sebagaimana tujuan dari program sekolah adiwiyata seperti, penebangan pohon sekitar sekolah secara tebang pilih, tidak mencabut tumbuhan sembarangan, tetap selalu menjaga kelestarian lingkungan sekitar, tidak mencoret-coret tembok sekolah, tidak menorehkan tulisan pada pohon, batubatuan, jalan maupun dinding, tidak membakar sampah disembaranagn tempat, melakukan kegiatan rutin membersihkan lingkungan, menimbun barang bekas dan membersihkan sampah-sampah yang tersumbat disaluran air. Dari berbagai macam wujud pelatihan kebiasaan sikap pembentukan karakter yang disiplin dan memilki kesadaran yang tinggi terhadap lingkungan sekitar sekolah. Dari program adiwiyata ini sendiri dapat membentuk karakter siswa mampu mengayomi nilai beretika lingkungan.

Menurut Tim Adiwiyata Nasional (Sitisyarah \& Mustika, 2017) keuntungan dari menyelenggarakan program sekolah adiwiyata yaitu:

1) Dapat memberikan dukungan terhadap suatu pencapaian standar kompetensi baik itu pendidikan dasar maupun pendidikan menengah;

2) Dapat memacu peningakatan efesiensi dari segi penggunaan operasional sekolah melalui pengehematan serta pengurangan baik itu pemakaian energy dengan berbagai sumber daya yang ada;

3) Dapat menjadikan tempat belajar yang aman dan nyaman bagi pengguna sekolah dengan selalu memahami nilai pemeliharaan dan pengelolaan lingkungan hidup yang baik dan benar bagi warga sekolah juga masyarakat sekitar;

4) Dapat menunjukkan sikap kebersamaan dengan menjunjung tinggi nilai-nilai norma dalam beretika secara kepedulian dan kesadaran lingkungan;

5) Dapat memberikan suatu bentuk pelestarian yang dapat digunakan secara bersama manfaat dari pogramnya.

\section{Sekolah Adiwiyata}

Sekolah sebagai suatu tempat dimana terjadinya proses belajar mengajar dengan cara mendidik dan dibimbing sesuai tenaga pendidik. Adiwiyata ialah sebuah program yang bertujuan untuk menciptakan pendidikan yang bermutu dan berkulitas atas dasar tercapainya suatu program. Jadi sebuah program adiwiyata yang dilaksanakan mengarah pada kepedulian lingkungan dan pelestarian lingkungan. Tujuan dari program sekolah adiwiyata ini mempunyai tanggung jawab terhadap tatakelola sekolah adiwiyata yang baik dan benar sehingga sekolah tetap terjaga keindahan dan kenyamanannya. (Hidayati et al., 2013). 


\section{METODE PENELITIAN}

Penelitian menggunakan metode penelitian kualitatif dengan pendekatan deskriptif. Penelitian ini telah dilaksanakan di SMA Negeri 15 Padang. Penentuan informan dilaksanakan dengan cara purposive sampling ialah teknik penentuan informan melalui pertimbangan yang dianggap bisa menghasilkan data yang akurat. Informan yang terdapat dalam penelitian ini SMA Negeri 15 Padang data yang diperoleh dari penelitian ini antara lain Wakil sarana dan prasarana SMA Negeri 15 Padang, ketua tim adiwiyata, guru, siswa yang terlibat dalam penerapan program sekolah adiwiyata di SMA Negeri 15 Padang. Data yang diperoleh dalam penelitian ini berbentuk dikumpulkan data primer dan sekunder. Data dikumpulkan berdasarkan hasil wawancara dengan beberapa warga sekolah SMA Negeri 15 Padang, data yang dikumpulkan melalui suatu obeservasi (pengamatan) wawancara serta studi dokumentasi. Uji keabsahan suatu data penelitian tersebut ialah dengan menggunakan metode triangulasi, sedangkan teknik analisis data didapatkan oleh reduksi data, display data atau mengambil kesimpulan hasil penelitian yang sudah terlaksana.

\section{HASIL DAN PEMBAHASAN}

\section{Implementasi Pelaksanaan Program} Sekolah Adiwiyata Di SMA N 15 Padang

Penerapan dari program sekolah adiwiyata tentu saja menimbulkan dampak, sebagaimana dijelaskan oleh (Bambang Tri Kurnianto, 2017), yang istilahnya bisa didefenisikan seperti sebab dan akibat. Dalam sebuah keputusan yang diperoleh seorang atasan biasanya menjadi dampak positif maupun dampak negatif. Dari penjelasan tersebut dapat di jelaskan bahwa dilaksankannya program sekolah adiwiyata.

Dimana dari implementasi pelaksanaan program sekolah adiwiyata di SMA N 15 Padang adalah adanya peningkatan efektivitas dalam pelaksanaan kegiatan secara operasional sekolah atau menggunakan berbagai sumber daya yang ada, dimana dalam mencapai tujuan dari program adiwiyata ini meliputi keseluruhan sumber daya yang ada disekolah baik sumber daya manusia maupun sumber daya alam.Ketika dilaksanakannya program sekolah adiwiyata ini, lingkungan sekolah terlihat lebih sehat dan asri dengan pemandangan hijau tanaman.

Menurut Weimer \& Vining(Ismail Nawawi, 2009) mengatakan ada 3 indikator variabel yang mempengaruhi keberhasilan suatu program kebijakan, yakni:

\section{1) Logika dari suatu program}

Program sekolah adiwiyata merupakan suatu program yang digalakkan oleh Kementrian Lingkungan Hidup bekerjasama dengan KEMENDIKBUD. SMA Negeri 15 Padang sekolah yang menerapkan cepat program adiwiyata ini sejak dikeluarkannya program ini oleh pemerintah, khususnya SMA yang berada di Kota Padang. Sekolah ini juga sudah menyandang peringkat sebagai sekolah adiwiyata mandiri.

Program sekolah adiwiyata dilaksanakan tidak lain dalam mewujudkan warga sekolah yang mau bertanggungjawab dalam setiap pengelolaan lingkungan hidupnya. Program adiwiyata melibatkan partisipasi semua pihak sehingga menyebabkan perubahan perilaku berbudaya lingkungan, juga meningkatkan mutu SDM dan mutu lingkungan hidup.

Berdasarkan hasil penelitian ini dilakukan di SMA Negeri 15 Padang, program sekolah adiwiyata sangat dibutuhkan pelaksanaanya di SMA Negeri 15 Padang karena sejak diberlakukannya program ini dapat memacu semangat warga sekolah untuk terus melaksanakan kegiatan rutin adiwiyata dengan waktu yang terus berlanjut demi merawatnya sekolah hijau, asri dan sehat. Bukti dari logika program adiwiyata ini memiliki manfaat yang banyak dan telah dianggap ideal yang bisa diterima dan bisa diukur dengan akal sehat secara rasional oleh warga sekolah. 
2) Sebuah program harus sesuai dengan tuntutan lingkungan

Sebuah program adiwiyata ini juga sedang gencar-gencarnya dilaksanakan oleh seluruh sekolah se Indonesia beberapa tahun ini. Penerapan program adiwiyata di SMA Negeri 15 Padang memang melakukan program ini berdasarkan aturan yang telah diberlakukan Kementrian Lingkungan Hidup dan Kementrian Pendidikan. Namun, beberapa tahun ini adiwiyata di SMA Negeri 15 Padang kurang terlaksana dengan baik. Hal ini dikarenakan terlihat dari beberapa fasilitas yang kurang terawat dengan baik.

Meskipun fasilitasnya terlihat kurang terawat tetapi kantin di SMA Negeri 15 Padang tetap menjalankan perintah untuk menerapkan kantin sehat, ini merupakan suatu perhatian dengan adanya makanan mengandung zat adiktif yang seharusnya tidak ada dimakanan. Berdasarkan hasil penelitian dilapangan menyatakan bahwa program yang telah dilakukan di SMA Negeri 15 Padang, belum sepenuhnya sesuai dengan tuntutan lingkungan. SMA Negeri 15 Padang dalam melaksanakan penanaman kesadaran perilaku terhadap sekolah dengan tuntutan lingkungan melakukan kebiasaan dengan kegiatankegiatan yang telah diprogramkan. Peneliti temukan seperti tempat sampah yang masih menggunakan kaleng cat seadanya, tempat buang sampah tersebut terbagi atas tiga kelompok namun dalam pembagian tersebut tanpa diberi tanda penjelasan sebagi pembeda jenis tempat sampah. Tempat sampah ini juga merupakan bagian dari kebutuhan yang mendukung tuntutan lingkungan, dengan demikian sekolah perlu kembali untuk memperhatikan serta memfasilitasi hal yang patut dijadikan sebagai penunjang program adiwiyata.

\section{3) Kemampuan implementor}

Hal lain yang merupakan meningkatkan mutu dari pelaksanaan program adiwiyata untuk upaya menghidari berbagai faktor pro kontra yang mana berdampak baik dan berdampak tidak baik maupun yang tidak mendukung program adiwiyata. Didalam pelaksanaan proses belajar dan menjadi tempat pembelajaran pengolaan yang melibatkan oknum-oknum yang ikut serta berpartisipas terhdap program sekolah adiwiyata. Hal ini dapat terwujud karena implemantor yang terlibat dapat menjalankan program sekolah adiwiyata ini agar peduli terhadap hidup sehat dan lingkungan disekitarnya serta dapat mengolah pembagian sampah organic, non organic disekolah.

Berdasarkan hasil penelitian dilapangan SMA Negeri 15 Padang sudah cukup mendukung program adiwiyata ini oleh seluruh perangkat warga sekolah. Dari program sekolah adiwiyata dapat menunjukkan partisipasi dari berbagai pihak baik itu guru-guru, karyawankaryawati, siswa-siswi, penjaga sekolah, petugas kebersihan. Dengan temuan semua warga sekolah berlaku dengan inisiatif sendiri, baik itu berpartisipasi aktif dalam pemecahan masalah lingkungan.

\section{Efektivitas Pelaksanaan Program Sekolah Adiwiyata Di SMA Negeri 15 Padang}

Efektivitas pelaksanaan program sekolah adiwiyata ialah suatu usaha dan kegiatan yang dapat memberikan inovasiinovasi baru dengan diterapkan pada pelaksanaan yang telah dirancang dengan secara terstruktur dalam kurun waktu yang ditentukan. Menurut Bapak Gusnaldi selaku Wakil sarana dan prasarana di SMA Negeri 15 Padang program ini sudah ada sejak Tahun 2013, program sekolah adiwiyata di SMA Negeri 15 Padang sudah pernah mendapatkat peringkat mandiri di Kota Padang pada waktu baru dilaksanakan program adiwiyata. Namun seiring berjalan waktu program ini berhasil apabila trjadi dampak dari efektiv dan efiennya.

Peneliti sudah melakukan wawancara seperti menanyakan tentang Efektivitas Pelaksanaan Program Sekolah Adiwiyata di SMA Negeri 15 Padang. Dimana dalam mengukur Efektivitas Pelaksanaan Program Sekolah Adiwiyata di SMA Negeri 15 
Padangpeneliti menggunakan teori yang dikemukakan oleh Budiani dalam (Amelia, 2015) diantaranya yaitu (1) Ketepatan sasaran program (2) Sosialisasi program (3) Pencapaian Tujuan program (4) Pemantuan program yaitu:

Ketepatan Sasaran Program.

Peneliti dapat mengetahui sejauh mana ketepatan sasaran Efektivitas Pelaksanaan Program Sekolah Adiwiyata di SMA Negeri 15 Padang. Aspek ketepatan sasaran program bisa dilihat dari perencanaan, yang selanjutnya dijalankan oleh sekolah di Kota Padang, salah satunya SMA Negeri 15 Padang. Dimana dalam implementasi program sekolah adiwiyata bertujuan untuk menciptakan pelestarian tanaman hijau.. Dimana untuk menjaga, merawat dan memelihara lingkungan sekolah harus memiliki sasaran yang tepat agar mencapai hasil yang ditujukan sesuai dengan tujuan dari SMA Negeri 15 Padang. Dari hasil temuan peneliti terungkap bahwa keteapatan sasaran program adiwiyata ini sudah tepat sasarannya seperti SDA maupun SDM dengan menjadikan program adiwiyata ini berjalan sesuai dengan tujuan dari SMA Negeri 15 Padang. Buktinya dengan dibentuknya Tim Adiwiyata SMA Negeri Padang dengan pelaksanaanya pada studi pembelajaran lingkungan hidup.

Sosialisasi Program.

Adapun aspek sosialisasi program ini bertujuan untuk membentuk kemampuan warga sekolah SMA Negeri 15 Padang dengan dilakukan pembekalan sosialisasi dalam melakukan sosialisasi program sekolah adiwiyata. Sosialisasi dapat dikatakan apabila adanya dua pihak yang mana pihak pertama memberikan sosialisasi secara aktif dan yang kedua sebai pihak penerima dari hasil yang telah disosialisaikan agar dapat berjalannya proses sosialisasi.(Abdullah \& Nasionalita, 2018).

SMA Negeri 15 Padang dengan adanya berbagai progres ketentuan yang bertujuan untuk melancarkan pelaksanaan program sekolah adiwiyata. Hasil penelitian menjelaskan bahwa Sosialisasi yang dilakukan oleh SMA Negeri 15 Padang melalui pemanggilan terhadap pedagang yang berjualan di lingkungan SMA Negeri 15 Padang agar memilah makanan yang akan dijual kepada siswa disesuaikan dengan aturan program adiwiyata, dimana makanan itu harus sehat. Dalam sosialisasi tersebut SMA Negeri 15 Padang juga menjelaskan mengenai ketentuan yang harus di ikuti oleh pedagang makanan berupa uji labor tentang pewarna, pemanis, pengawet dan penyedap makanan.

Selanjutnya sosialisasi juga diberikan kepada warga sekolah. Warga sekolah itu terdiri dari siswa/i, guru-guru, karyawan/i SMA Negeri 15 Padang. Sosialisasi yang diberikan kepada warga sekolah tersebut berupa pengumpulan siswa dilapangan setelah upacara yang bertujuan untuk memberikan himbuan kepada siswa-siswi mengenai kebijakan program adiyiwata yang dilaksanakan di SMA Negeri 15 Padang. Dalam memberikan sosialisasi ini, sekolah mengalami beberapa kendala yaitu beberapa siswa tidak menghiraukan himbauan yang diberikan oleh kepala sekolah.

Solusi dari masalah ini yaitu dengan memberikan aturan-aturan yang harus ditaaati oleh siswa-siswi untuk menunjang program sekolah adiwiayta yang dituangkan dalam kertas dan dipajang disetiap kelas. Bentuk sosialisasi lainnya adalah yaitu berbentuk reklame dan poster yang bertemakan tentang visi dan misi sekolah mengenai adiwiyata seperti menciptakan peranan warga sekolah terhadap lingkungan. Agar poster dan reklame ini diperhatikan oleh warga sekolah maka penempatannya pun diletakkan secara strategis yaitu daeahdaeah yang paling sering dilalui warga sekolah seperti didepan kelas, didepan ruang guru, didepan ruang tata usaha, 
didepan perpustakaan, didepan laboraturium dan juga jalan menuju kantin.

\section{Pencapaian Tujuan Program}

Dalam aspek pencapaian tujuan pada program sekolah adiwiyata dilihat dari sekolah adiwiyata yang diterapkan di SMA Negeri 15 Padang sehubungan dengan hal tersebut pada pelaksanaan program sekolah adiwiyata berdasarkan penelitian ini telah dilakukan melalui wawancara dapat dikatakan bahwa pada implementasi program sekolah adiwiyata jika dilihat efektivitasnya terhadap peningkatan kepedulian siswa sudah cukup efektif. Namun, dalam pelaksanaan program sekolah adiwiyata diterapkan di SMA Negeri 15 Padang bukan hanya siswa, namun juga termasuk seluruh aspek yang terlibat pada sekolah tersebut.

Berdasarkan wawancara yang telah dilakukan ditemukan bahwa pelaksanaan program sekolah adiwiyata sudah cukup efektif dilaksanakan bagi siswa maupun guru dan karyawan-karyawati di SMA Negeri 15 Padang. Dimana berdasarkan wawancara yang telah dilakukan ditemukan bahwa kebijakan yang dibuat pada program sekolah adiwiayata dapat melatih siswa agar lebih peduli tehadap lingkungan dan juga hidup lebih sehat. Hal ini dibuktikan dengan antusias setiap kelas untuk menampilkan kelasnya menjadi kelas yang bersih, tertata rapi, dengan tanaman hijau yang terdapat didepan kelas dan beberapa lainnya disudut dalam kelas. Bukti dari siswa-siswi hidup lebih sehat yaitu makanan yang dijual disekolah harus bersih dan sehat serta lulus uji labor. Selain siswa sasaran dari program ini adalah guru-guru, serta seluruh karyawan-karyawati yang ada di SMA Negeri 15 Padang. Mereka merupakan mediator bagi siswa dalam menerapkan program sekolah adiwiyata yang diterapkan baik pada saat proses pembelajaran maupun diluar kegiatan pembelajaran dikelas.
Terdapat beberapa hambatan pada pencapaian tujuan dari sekolah seperti terdapatnya warga sekolah yang melanggar aturan kebijakan didalam program sekolah adiwiyata seperti merokok dan juga kurang menjaga kebersihan lingkungan sekolah jika bukan pada kelas yang siswa itu tempati. Untuk menanggapi hal tersebut SMA Negeri 15 Padang dapat melakukan upaya dengan cara melakukan razia secara rutin bagi siswa yang merokok serta memberikan penyuluhan kepada siswa tentang bahaya merokok, baik bagi kesehatan, psikologis, maupun ekonomi. Selain itu utuk mengatasi kendala pada program ini, sekolah bisa melakukan upaya dengan memberikan apresiasi terhadap siswa yang peduli terhadap lingkungan sekolah selain lingkungan kelasnya saja.

\section{Pemantauan Program}

Aspek pemantauan program sekolah adiwiyata dilakukan setelah dilaksanakannya kegiatan untuk peserta program. Dimana peserta dalam program ini adalah warga sekolah. Sistim pemantauan atau pengawasan dan pengendalian bersifat mendidik dapat didefenisikan sebagai perasaan yang baik dimiliki seseorang yang diinginkan terjadi maka terjadilah kepuasan(Mubarak \& Putri, 2020) .

Berdasarkan pemantauan yang telah dilakukan oleh Tim Sekolah Adiwiyata Kota Padang melalui Dinas Pendidikan Sumatera Barat kepada SMA Negeri 15 Padang adalah dengan melakukan pemantauan terhadap kebutuhan sarana dan prasarana yang menunjang program tersebut, ketercapaian yang telah dicapai oleh SMA Negeri 15 Padang dalam menerapkan program adiwiyata. Selama ini laporan secara tertulis mengenai prospek terlaksananya program sekolah adiwiyata tidak ada, sehingga peneliti hanya bisa mengetahui dari wawancara yang diberikan dan pemantauan langsung lingkungan 
sekitar SMA Negeri 15 Padang. Serta kurangnya kejelasan mengenai progress di SMA Negeri 15 Padang secara tertulis sehibgga menimbulkan situasi yang leu terhadap rencana-rencana program kedepannya yang seharusnya dilaksanakan.

\section{PENUTUP}

Berdasarkan penelitian yang telah dilakukan di atas dapat diambil beberapa kesimpulan oleh penulis tentang efektivitas pelaksanaan program sekolah adiwiayata di SMA Neger 15 Padang yaitu :

1. Pelaksanaan program sekolah adiwiyata di SMA Negeri 15 Padang melibatkan seluruh warga sekolah. Sector-sektor yang terlibat dalam pelaksanaan ini berupa pembenahan taman hijau menjadi lebih tertata rapi, pengolahan sampah, pengaplikasian sikap peduli lingkungan oleh anak yang diterapkan selama belajar dikelas. Namun untuk sector pengolahan sampah belum terlaksana dengan baik, serta kurangnya penjelasan mengenai laporran secara tertulis mengenai pencapaian yang telah didapatkan oleh SMA Negeri 15 Padang pada program sekolah adiwiyata.

2. Berdasarkan pelaksanaan Program Sekolah Adiwiyata yang dilaksanakan di SMA Negeri 15 Padang sudah cukup efektif namun belum 100\% dalam mewujudkan kepedulian siswa untuk lingkungan, hal ini dibuktikan dengan kurangnya kejelasan secara tertulis maupun praktek mengenai kelanjutan program ini untuk kedepannya.

\section{DAFTAR KEPUSTAKAAN}

Abdullah, N. N., \& Nasionalita, K. (2018). Pengaruh Sosialisasi Terhadap Pengetahuan Pelajar Mengenai Hoax (Studi Pada Program Diseminasi Informasi Melalui Media Jukrak Di SMKN 1 Pangandaran). CHANNEL: Jurnal Komunikasi, 6(1), 120. https://doi.org/10.12928/channel.v6i1. 10217
Akib, H. (2012). Implementasi Kebijakan: Apa, Mengapa dan Bagaimana. Jurnal Ilmiah Ilmu Administrasi Publik. https://doi.org/10.26858/jiap.v1i1.289

Amelia, R. (2015). Efektivitas Pelaksanaan Program Penanganan Anak Jalanan Di Dinas Sosial Kota Makassar. Skripsi [Internet].[Diunduh Pada 28 Maret 2016]. Tersedia Pada: Http://Repository. Unhas. Ac. Id/Bitstrea m/Handle/123456789/14610/SKRIPSI $\%$ 20RIZCAH\% 20AMELIA. Pdf, 1111.

Bambang Tri Kurnianto. (2017). Dampak Sosial Ekonomi Masyarakat Akibat Pengembangan Lingkar Wilis Di Kabupaten Tulungagung. Jurnal AGRIBIS, 13(15), 55-85.

Hidayati, N., Taruna, T., \& Purnaweni, H. (2013). Perilaku Warga Sekolah Dalam Program Adiwiyata di SMK Negeri 2 Semarang. Prosiding Seminar Nasional Pengelolaan Sumberdaya Alam Dan Lingkungan.

Ismail Nawawi. (2009). Public Policy: Analisis. Strategi Advokasi Teori Dan Praktik. In Public Policy: Analisis. Strategi Advokasi Teori Dan Praktik.

Kahfi, A. (2014). Kejahatan Lingkungan Hidup. Al-Daulah, 3(2), 206. http://dx.doi.org/10.1016/S00165085(12)60771-9

Mubarak, A., \& Putri, N. E. (2020). Implementation of Environmental Protection and Management Policies in Padang Panjang City. https://doi.org/10.2991/aebmr.k.20030 5.183

Sitisyarah, K., \& Mustika, R. (2017). Penerapan Program Adiwiyata Di Smp Negeri 13 Palembang. JMKSP (Jurnal Manajemen, Kepemimpinan, Dan 
Supervisi Pendidikan), 2(1), 143-155.

https://doi.org/10.31851/jmksp.v2i1.1

161

Sumarlin. (2013). Persepsi dan Kepedulian

Siswa terhadap Pengelolaan

Lingkungan melalui Program

Adiwiyata. In Majalah Geografi

Indonesia (Vol. 27, Issue 1, pp. 38-

$55)$. 